\title{
Comparative biometric study of sardine Sardina pilchardus (Walbaum, 1792) of the Algerian littoral (Actinopterygii Clupeiformes Clupeidae)
}

\author{
Aïcha Benaldjia ${ }^{*}$, Lyamine Mezedjri² \& Ali Tahar'
}

\begin{abstract}
${ }^{1}$ Department of Biology, Faculty of Sciences, Badji Mokhtar University, 23000 Annaba, Algeria; e-mail: benalenvironnement@gmail.com

${ }^{2}$ Department of Natural Sciences and Life, Faculty of Sciences, 20 August 1955 University, 21000 Skikda, Algeria; e-mail: mezedjri.lyamine@gmail.com

${ }^{*}$ Corresponding author
\end{abstract}

ABSTRACT

A compared biometric study of the sardine Sardina pilchardus (Walbaum, 1792) (Actinopterygii Clupeiformes Clupeidae) was carried on 471 specimens during the year 2015. These samples were taken from seven different sites of the Algerian coast going from the east to the west: El Kala, Annaba, Skikda, Collo, Jijel, Algiers, and Oran. The ANOVA test which was applied on each of the 36 variables morphometric and meristic shows that there is a highly significant difference between the seven sites for 35 variables out of 36 . However, concerning the sex factor in the study area, we didn't note significant differences between sexes. The comparison of the seven sites with the MANOVA test confirms the results obtained by the ANOVA.

KEY WORDS

Algerian coastline; compared biometric; MANOVA; Sardina pilchardus.

Received 05.02.2019; accepted 02.07.2019; published online 18.08.2019.

\section{INTRODUCTION}

Fishing practiced on the Algerian basin targets a great variety of pelagic species, and among these species we find the sardine, Sardina pilchardus (Walbaum, 1792) (Actinopterygii Clupeiformes Clupeidae), which is the subject of this work by a disembarkation or landing of $40 \%$ to $50 \%$ of the overall national fish disembarkation. Sardina pilchardus has already been the topic of many studies, biologic and morphologic. We can cite those of Furnestin (1950), Lee (1961), (Aldebert \& Tournier 1971), Ettahiri et al. (1998), Amenzoui et al. (2005), Khemiri (2006), Chlaida (2009), Kaidi (2011), and Nikolioudakis et al. (2011).

\section{MATERIAL AND METHODS}

This study was achieved during the year 2015, on the fish which was bought from fishmongers of the concerned regions: El Kala, Annaba, Skikda, Collo, Jijel, Algiers and Oran (Fig. 1).

According to the fishmongers, this fish is fished with the help of a fishing device, as fillet and mesh, and a sample of 30 individuals minimum is taken in to consideration, for every zone. Each individual is enveloped by a film in plastic immediately after the collection to avoid its damage, and then it is put in the freezer, at a temperature of $-20{ }^{\circ} \mathrm{C}$. In the laboratory, a set of 36 morphometric and meristic measures was obtained 
on every fish (Fig. 2, Table 1). All the metric measures were realized in millimeters with the help of a dry compass. The meristic measures were done under a binocular magnifier with a reckoning; the fixing of the sex was realized after the dissection of the fish.

To describe better the various variables which characterize individuals, we calculated some basic statistical parameters such as the arithmetic average, the standard deviation (s) which measures the dispersion of the data around the mean, the minimal xmin and maximal xmax values which both give an idea of the extent of the data, and finally, the size which informs us about the handled importance of the data. To compare the averages for each of the 36 characteristics among the seven sites, we used the one-way variance analysis test or the fixed model classification factor. This test consists in comparing the averages of several populations from random, simple, and ample independent data (Dagnelie, 1970, 2006).

The comparison of the seven sites between them for the set of the studied variables, realized by means of the analysis of the multivariate variance by using three statistical tests, are: Wilk's, LawleyHotteling \& Pillai's (Dagnelie, 2000). All the calculations were executed with the software statistical
Minitab of analysis and treatment of the data, version 17 of the software (X, 2015).

\section{RESULTS}

According to the results obtained in the description of the data of 471 individuals, we noticed that the largest size is recorded in females of El Kala and Oran with a length of $19 \mathrm{~cm}$. On the other side, the smallest size is noticed in the indeterminated sex with only $9.20 \mathrm{~cm}$ (see also Tables 2, 3). The females of El Kala, Jijel, and Oran have larger sizes than the males and it is the reverse in other sites, where the males are longer than females (Tables 3 ).

The comparison between the averages of the variables of the two sexes in each site tell us that the averages of the females in the gulfs of Algiers, El Kala, Jijel, and Oran, Collo, Skikda are slightly higher than those of the males. This is not the case for those of the Annaba who are a bit higher than females. This may suggest a possible sexual dimorphism in our species.

The results of the univariate fixed variance analysis test applied to each of the 36 variables measured appear in the Table 2 for comparison between sites and both sexes in each site show that

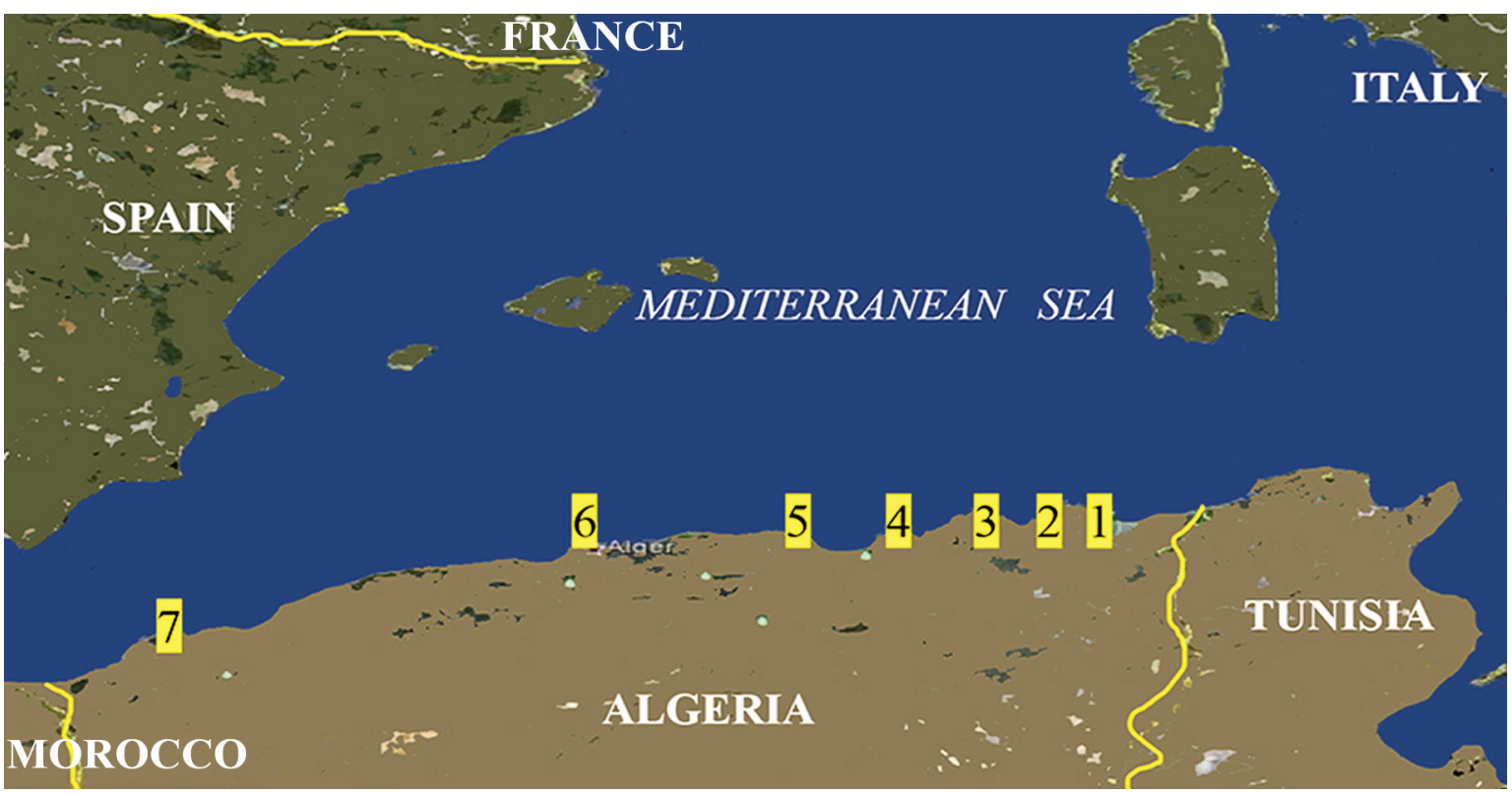

Figure 1. Study area, location of sampling sites: (1) El Kala Gulf, (2) Gulf of Annaba, (3) Gulf of Skikda, (4) Gulf of Collo, (5) Gulf of Jijel, ( 6) Bay of Algiers, (7) Gulf of Oran. 
there is a highly significant meristic and morphometrical difference between the sites for 35 out of 36 variables, as well as very highly significant sex differences in the seven sites studied for: Lt, Lf, Dopv, at level $\alpha=0.1 \%$. Highly significant difference for Ls, Lpan, Lppv, Lpdo at level $\mathrm{a}=1 \%$ and differences just significant for Lppc, Doan. Lman, Lain, Lapc, Hpc, Hpd. Bado, Baan, pvan, brus at level $\alpha=5 \%$. The variables giving significant differences can be retained for the demonstration of sexual dimorphism of this species.

The test of MANOVA has been applied on 2 matrixes of data using three tests, Wilk's, LawleyHotelling and Pillai's) with the same results. This means that there are very highly significant differences between the 36 variables in the seven sites (Table 4). However, the three tests show the absence of any significant difference between the two sexes in each site for all the 36 variables (Table 5).

The noticed differences can be explained by the difference in sardine diet in each site, the physiological state of the individuals at the time of sampling and even the period of sampling as well as the pollution by the discharges of the different origins that change the physio-chemical parameters of the environment, which consequently deteriorate the aquatic ecosystem and the life cycle of its populations. According to Grimes (2010), most cities of the Algerian littoral suffer from a type of pollution that is related to the dominant activity in each city.

\section{CONCLUSIONS}

This work aims at a morphometrical comparison of the sardine of the Algerian littoral. The study is carried out on 471 specimens sampled in random manner. In this study it was possible to note by means of a comparison between the averages of the variables of both sexes in each site and the existence of an eventual sexual dimorphism in this species. The well determined statistical tests that were used show that there is a very highly significant difference between the 7 sites for the 35 biometrical variables upon 36 studied at our species, therefore our study constitutes a data base on which other studies are based in order to better understand the causes of this difference noticed in the sardine of the Algerian coast, for instance, a genetical study of the species.

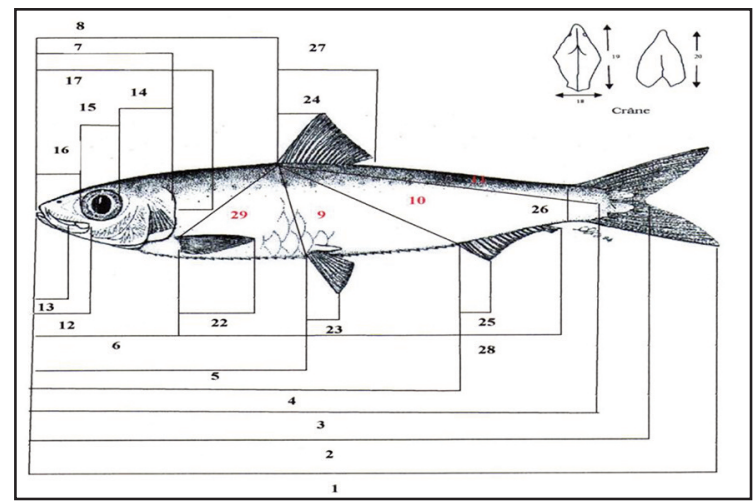

Figure 2. Morphometric measurements made on each fish.

\begin{tabular}{|c|c|c|}
\hline Number & Code & Description \\
\hline \multicolumn{3}{|c|}{$\begin{array}{l}\text { Morphometric } \\
\text { measurements }\end{array}$} \\
\hline 1 & Lt & Total length \\
\hline 2 & Lf & At fork length \\
\hline 3 & Ls & Standard length \\
\hline 4 & Lpan & Length pre-anal \\
\hline 5 & Lppv & Length pre-pelvic \\
\hline 6 & Lppc & Length pre-pectoral \\
\hline 7 & Lcep & Cephalic length \\
\hline 8 & Lpdo & Length pre-dorsal \\
\hline 9 & Dopv & Dorsal / pelvic distance \\
\hline 10 & Doan & Dorsal / anal distance \\
\hline 11 & Doca & Dorsal / Caudal Distance \\
\hline 12 & Lman & Mandible length \\
\hline 13 & Lmax & Maxillary length \\
\hline 14 & Poor & Distance post-orbitaire \\
\hline 15 & Dor & Diameter Orbital \\
\hline 16 & Pror & Length Pre-orbital \\
\hline 17 & Lpop & Length pre-operculum \\
\hline 18 & Lain & Inorbital Width \\
\hline 19 & Lcra & Head width \\
\hline 20 & Mist & Length mandible / isthmus \\
\hline 21 & Lapc & Distance between pectoral insertions \\
\hline 22 & $\mathrm{Hpc}$ & Pectoral Height \\
\hline 23 & $\mathrm{Hpv}$ & Pelvic Height \\
\hline 24 & Hdo & Dorsal Height \\
\hline 25 & Han & Anal Height \\
\hline 26 & $\mathrm{Hpdc}$ & Peduncle Height \\
\hline 27 & Bado & Dorsal Height \\
\hline 28 & Baan & Anal Height \\
\hline 29 & Dopc & Distance dorsal/pectoral \\
\hline 30 & Pcpv & Distance pectoral/pelvic \\
\hline 31 & Pvan & Distance pelvic/anal \\
\hline \multicolumn{3}{|c|}{ Meristic counting } \\
\hline 32 & $\mathrm{Cæc}$ & Cæc Number of pyloric caeca \\
\hline 33 & Brin & $\begin{array}{l}\text { Number of lower gill rakers of the 1st } \\
\text { left branchial arch }\end{array}$ \\
\hline 34 & Brsu & $\begin{array}{l}\text { Number of upper gills rakers of the } 1 \text { st } \\
\text { left branchial arch }\end{array}$ \\
\hline 35 & Rypc & Number of rays of the left chest \\
\hline 36 & Rypv & Number of left pelvic rays \\
\hline
\end{tabular}

Table 1. Morphometric and Meristic Studied Variables. 


\begin{tabular}{|c|c|c|c|c|c|}
\hline \multicolumn{6}{|c|}{ Factors } \\
\hline \multirow[b]{2}{*}{$n^{o}$} & \multirow[b]{2}{*}{ Variables } & \multicolumn{2}{|l|}{ Site } & \multicolumn{2}{|c|}{ Sex (sites) } \\
\hline & & $\mathrm{F}$ & $\mathrm{P}$ & $\mathrm{F}$ & $\mathrm{P}$ \\
\hline 1 & $\mathrm{Lt}$ & 1124.9 & $0.000 * * *$ & 3.66 & $0.001 * * *$ \\
\hline 2 & Lf & 32.41 & $0.000 * * *$ & 3.94 & $0.000 * * *$ \\
\hline 3 & Ls & 113.47 & $0.000 * * *$ & 3.35 & $0.002 * *$ \\
\hline 4 & Lpan & 113.75 & $0.000 * * *$ & 3.33 & $0.002 * *$ \\
\hline 5 & Lppv & 106.28 & $0.000 * * *$ & 3.23 & $0.002 * *$ \\
\hline 6 & Lppc & 52.13 & $0.000 * * *$ & 2.08 & $0.045 *$ \\
\hline 7 & Lcep & 59.26 & $0.000 * * *$ & 1.77 & $0.091 \mathrm{~ns}$ \\
\hline 8 & Lpdo & 95.30 & $0.000 * * *$ & 3.24 & $0.002 * *$ \\
\hline 9 & dopv & 66.43 & $0.000 * * *$ & 4.53 & $0.000 * * *$ \\
\hline 10 & doan & 85.19 & $0.000 * * *$ & 2.62 & $0.012 *$ \\
\hline 11 & doca & 88.25 & $0.000 * * *$ & 1.65 & $0.119 \mathrm{~ns}$ \\
\hline 12 & Lman & 73.40 & $0.000 * * *$ & 2.16 & $0.036 *$ \\
\hline 13 & Lmax & 48.49 & $0.000 * * *$ & 1.49 & $0.169 \mathrm{~ns}$ \\
\hline 14 & Poor & 75.91 & $0.000 * * *$ & 1.27 & $0.262 \mathrm{~ns}$ \\
\hline 15 & Dor & 23.93 & $0.000 * * *$ & 0.95 & $0.471 \mathrm{~ns}$ \\
\hline 16 & Pror & 54.59 & $0.000 * * *$ & 1.85 & $0.076 \mathrm{~ns}$ \\
\hline 17 & Lpop & 68.91 & $0.000 * * *$ & 1.85 & $0.076 \mathrm{~ns}$ \\
\hline 18 & Lain & 41.02 & $0.000 * * *$ & 2.42 & $0.019 *$ \\
\hline 19 & Lcra & 77.55 & $0.000 * * *$ & 1.26 & $0.267 \mathrm{~ns}$ \\
\hline 20 & Mist & 57.36 & $0.000 * * *$ & 1.18 & $0.315 \mathrm{~ns}$ \\
\hline 21 & Lapc & 6.36 & $0.000 * * *$ & 2.31 & $0.025 *$ \\
\hline 22 & $\mathrm{Hpc}$ & 78.75 & $0.000 * * *$ & 2.12 & $0.040 *$ \\
\hline 23 & $\mathrm{Hpv}$ & 2.23 & $0.039 *$ & 0.08 & $0.999 \mathrm{~ns}$ \\
\hline 24 & Hdo & 62.40 & $0.000 * * *$ & 1.83 & $0.080 \mathrm{~ns}$ \\
\hline 25 & Han & 20.88 & $0.000 * * *$ & 0.87 & $0.532 \mathrm{~ns}$ \\
\hline 26 & Hpdc & 37.05 & $0.000 * * *$ & 2.16 & $0.318 \mathrm{~ns}$ \\
\hline 27 & Bado & 85.03 & $0.000 * * *$ & 2.16 & $0.036 *$ \\
\hline 28 & Baan & 9.54 & $0.000 * * *$ & 2.06 & $0.047 *$ \\
\hline 29 & dopc & 68.86 & $0.000 * * *$ & 1.87 & $0.073 \mathrm{~ns}$ \\
\hline 30 & pcpv & 63.25 & $0.000 * * *$ & 1.68 & $0.111 \mathrm{~ns}$ \\
\hline 31 & pvan & 66.14 & $0.000 * * *$ & 2.65 & $0.011 *$ \\
\hline 32 & cæc & 37.25 & $0.000 * * *$ & 0.73 & $0.646 \mathrm{~ns}$ \\
\hline 33 & brin & 45.49 & $0.000 * * *$ & 1.00 & $0.433 \mathrm{~ns}$ \\
\hline 34 & brsu & 54.79 & $0.000 * * *$ & 2.14 & $0.039 *$ \\
\hline 35 & rypc & 35.34 & $0.000 * * *$ & 1.08 & $0.375 \mathrm{~ns}$ \\
\hline 36 & rypv & 23.96 & $0.000 * * *$ & 0.63 & $0.730 \mathrm{~ns}$ \\
\hline
\end{tabular}

Table 2. Results of the analysis of variance at a fixed model classification criterion of the comparison, between sites and sexes (sites), of the means of each of the 36 variables. $\mathrm{P}>5 \%$ : not significant difference. ${ }^{*} \mathrm{p}=5 \%$ : significant difference. ${ }^{*} \mathrm{P}=1 \%$ : highly significant difference. ${ }^{* *} \mathrm{p}=0.1$ : very highly significant difference. $\mathrm{F}=$ value of $F_{o b s} . \mathrm{P}=$ probability. 


\begin{tabular}{|c|rll|lll|}
\hline Sites & \multicolumn{3}{|c|}{ Males } & \multicolumn{3}{c|}{ Females } \\
\hline & n & L max & L min & n & L max & L min \\
El-kala & 40 & $16.10 \mathrm{~cm}$ & $10.50 \mathrm{~cm}$ & 29 & $19 \mathrm{~cm}$ & $11.20 \mathrm{~cm}$ \\
Annaba & 48 & $15.60 \mathrm{~cm}$ & $10.50 \mathrm{~cm}$ & 11 & $14.5 \mathrm{~cm}$ & $9.50 \mathrm{~cm}$ \\
Skikda & 53 & $15 \mathrm{~cm}$ & $9.50 \mathrm{~cm}$ & 23 & $14 \mathrm{~cm}$ & $10 \mathrm{~cm}$ \\
Collo & 44 & $15.40 \mathrm{~cm}$ & $11.10 \mathrm{~cm}$ & 67 & $15.10 \mathrm{~cm}$ & $11.10 \mathrm{~cm}$ \\
Jijel & 8 & $14.90 \mathrm{~cm}$ & $9.70 \mathrm{~cm}$ & 22 & $14.20 \mathrm{~cm}$ & $10 \mathrm{~cm}$ \\
Alger & 48 & $14.90 \mathrm{~cm}$ & $9.70 \mathrm{~cm}$ & 23 & $14.20 \mathrm{~cm}$ & $10 \mathrm{~cm}$ \\
Oran & 18 & $18.50 \mathrm{~cm}$ & $16 \mathrm{~cm}$ & 15 & $19 \mathrm{~cm}$ & $14.50 \mathrm{~cm}$ \\
\hline
\end{tabular}

Table 3. Description of the data for each site.

\begin{tabular}{|l|l|l|l|}
\hline Tests & $\begin{array}{l}\text { Observed values } \\
\text { of the test }\end{array}$ & Fobs & $\mathrm{P}$ \\
\hline Wilks' & 0.01150 & 12.598 & $0.000^{* * *}$ \\
$\begin{array}{l}\text { Lawley- } \\
\text { Hotelling } \\
\text { Pillai's }\end{array}$ & 9.07058 & 17.021 & $0.000^{* * *}$ \\
\hline
\end{tabular}

Table 4. MANOVA for Sites. Multivariate tests used to test the equality of mean vectors between sites. $P \leq \alpha=0,001$ : $(* * *)$ very highly significant differences.

\section{REFERENCES}

Amenzoui K., Ferhan-Tachinante F., Yahyaoui A., Mesfioui A. \& Kifani S., 2005. Etude de quelques aspects de la reproduction de Sardina pilchardus (Walbaum, 1792) de la région de Laâyoune (Maroc). Bulletin de 1'Institut Scientifique, Rabat, section Sciences de la Vie, 26: 43-50.

Chlaida M., 2009. Variabilité allozymique associée au flux migratoire des populations de sardine Sardina pilchardus le long de la côte nord ouest africaine. Thèse de Doctorat, Université Mohammed V. Agdal, Maroc, 96 pp.

Dagnélie P., 1970. Théorie et méthodes statistiques: applications agronomiques (vol. 2). Presses agronomiques, Gembloux, 451 pp.

Dagnélie P., 2000. Statistique théorique et appliquée. Tome 2: Inférences à une et à deux dimensions. De Boeck et Larcier, Bruxelles-Université, 659 pp.

Furnestin J., 1950. Les races de sardines du détroit de Gibraltar et ses bords. Rapports et procés-verbaux des

\begin{tabular}{|l|l|l|l|}
\hline Tests & $\begin{array}{l}\text { Observed values } \\
\text { of the test }\end{array}$ & Fobs & $\mathrm{P}$ \\
\hline Wilks' & 0.51080 & 1.145 & $0.066 \mathbf{n s}$ \\
$\begin{array}{l}\text { Lawley- } \\
\text { Hotelling } \\
\text { Pillai's }\end{array}$ & 0.71231 & 1.146 & $0.065 \mathbf{~ n s}$ \\
\hline
\end{tabular}

Table 5. MANOVA for sexes (sites). Multivariate tests used to test the equality of mean vectors between the two sexes in the sites. $p>\alpha=0,05:$ (ns) not significant.

réunions Commission internationale pour l'exploration scientifique de la Mer Méditerranée, 126: 6267.

Grimes S., 2010. Peuplements benthiques des substrats meubles de la côte Algérienne: taxonomie, structure et statut écologique. Thèse de Doctorat, Université d'Oran, Algérie, 362 pp.

Kaidi S., Ramadane Z., Amara R., Zebboudj A., Soualmi A., Igerouada M. \& Karrah H., 2011. Étude de quelques aspects de la reproduction de Sardina pilchardus (Walbaum, 1792) dans la région d'Annaba. Algérie. 3ème Séminaire Internationale de Biologie Animale (SIBA) Mentouri. Constantine abstract book. Khemiri S., 2006. Reproduction, âge et croissance de trois téléostéens pélagiques des côtes tunisiennes: $E n$ graulis encrasicolus, Sardina pilchardus et Boops boops. Thèse de Doctorat en Halieutique. École nationale supérieure agronomique de Rennes, 194 pp.

Lee J., 1961. Note complémentaire sur les sardinelles Sardinella aurita (Valenciennes, 1847) du golfe du Lion. Rapports et procés-verbaux des réunions Com- 
mission internationale pour l'exploration scientifique de la Mer Méditerranée, 16: 335-339.

Nikolioudakis N., Palomera I., Machias A. \& Somarakis S., 2011. Diel feeding intensity and daily ration of the sardine Sardina pilchardus. Marine Ecology Progress Series, 437: 215-228. https://doi.org/10.3354/meps 09275

X., 2015. Minitab version 17 for Windows. 